\title{
Cultural and Social Changes in Education: A Canadian Case Study
}

\begin{abstract}
By Richard D. Christy ${ }^{*}$
In a credential society such as Canada university degrees, college certificates, and trade school diplomas are essential for social and economic success. Too often social economic status, race, religion, class, and family values have been barriers to post-secondary education. In his classical study of Canada society, Porter argues that more than ever "education means opportunity" (Porter1965, 167). Income is identified by Porter as one of the enduring barriers to education. As the ninth strike by Quebec students since 1968 indicates, income and student debt continues to be a major flashpoint in post-secondary education. In this paper, I will examine the rising costs of education and changing university funding in Canada. While Porter identified income as a major barrier to education, I will also examine the current debates on gender and educational participation. Are boys in academic trouble? Has the class room and teachers become anti-male? What, if anything, can be done to address this perceived or real problem?
\end{abstract}

\section{Introduction}

In September of 1961 my Father and I drove from our family farm to the small rural branch of the Bank of Nova Scotia in North Augusta Ontario to borrow money for my first year at the Ontario Agricultural College, University of Guelph. When my Father returned to the car he handed me a check for $\$ 1,680.00$ for my tuition, fees and room and board and said "this is your first year and after that you are on your own." I replied, always being the optimist, "this is the best investment you have ever made!" My Dad, always being the realist, said "we will see". In 1977 I received my $\mathrm{PhD}$ from the University of Toronto. I graduated with a university education financed by summer jobs, a modest student loan of $\$ 3,500.00$ at a $3 \%$ interest rate, graduate scholarships, and part time teaching. I did not know the amount of money I needed for my university degrees. I also had no clear idea about my future career. I assumed that after my graduation I would have a job with few if any financial or gender barriers, and that any educational debt could be handled.

How has the Canadian educational system changed? According to recent CAUT (Canadian Association of University Teachers) data; the average tuition rate in Ontario is $\$ 6,307$. According to Statistics Canada and the Canadian Association of University Teachers students graduating with at the Bachelor's

*Associate Professor of Sociology, Wilfrid Laurier University, Canada. 
level will be, on average, $\$ 32,000$ in debt. Students undertaking a further university degree at the Master's level will see this rise to $\$ 35,100$ and should a doctorate be pursed the average indebtedness is $\$ 42,800$. While the cost of education has dramatically changed, the necessity for a post-secondary education and accreditation is increasingly essential in post-modern society.

In his classic study Vertical Mosaic: An Analysis of Social Class and Power in Canada Porter notes that because of the complex division of labor in modern society, education has come to be one of the most important social functions. Porter writes that both "the quantity and quality of education which determines a society's potential" (Porter1965, 164). While there has been tremendous growth in the Canadian educational system, Porter argues that there are enduring psychological and social barriers to equal opportunity. $\mathrm{He}$ writes that the psychological barriers to education are the attitudes, values and motives and the social barriers are: 1) inequality of income and wealth, 2) family size 3) regional differences in educational facilities and 4) religious influences on educational policy. In this paper I will examine the financial barriers facing university students and highlighted in Quebec by protests over increased tuition. I will also examine whether gender is a social barrier facing Canadian boys and men.

\section{Educational Funding: Government and Tuition}

The 1867 British North America Act gave jurisdiction over education to the provinces of Canada. Except for a few federal schools and private schools, most elementary and secondary schools in Canada are administered by local school boards operating under provincial statutes. According to Statistics Canada, in 2001/2002 local school boards across Canada spent $\$ 35.7$ billion. Of this revenue, $\$ 8.0$ billion was collected from local property taxes, $\$ 25.5$ billion from government transfers payments and $\$ 2.2$ billion from fees and other income sources. In 2001, education represented $15 \%$ of government expenditures compared to $17 \%$ for health.

In the 2012 Harris/Decima survey conducted for CAUT (Canadian Association of University Teachers) "nearly 80 per cent of Canadians believe getting a university or college education is more important than ever, but most say it's also more difficult to pursue post-secondary studies because of costs." (CAUT Bulletin2011, A5). The enrolment in Canadian universities and colleges indicate that students agree with the importance of education. According to the 2011-2012 CAUT Almanac the participation rate of 21 year olds in university education grew from $12 \%$ in $1972-1973$ to $29 \%$ in 2008 2009 and the participation rate of students 18-24 was 17\% in 1992-1993 and was $23 \%$ in 2008-2009. "Full time university enrolment grew from 592.320 in 1999-2000 to 836,685 in 2008-2009 an increase of 41\%." (CAUT Almanac 2012, 23).

The provincial expenditures on post-secondary education in Canada have increased dramatically over the past thirty years. Between 1980 and 2009 total 
university expenditures increased by 193\%. (CAUT Almanac 2012, 1). According to the CAUT Almanac the total expenditure on post-secondary education rose from $\$ 14$ billion in 1992-1993 to $\$ 19$ billion representing a $30.8 \%$ increase. The greatest increase in government funding from 1992-1993 to 2008-2009 has been in the western provinces with Saskatchewan with a 96.4\% increase, Alberta with a 94.6\% increase and by contrast Quebec with an $8.1 \%$ increase.

The significance of education in post-modern Canada has resulted in more federal and provincial financial resources directed to post-secondary education. In spite of rising government expenditures the costs of education continues to be identified as a barrier to education. During the recent student protest in Quebec, Roxanne Dubois of the Canadian Federation of Student stated that "tuition fees are much too high in Canada and they act as the main barrier preventing young people from pursuing their post-secondary education." (CAUT Bulletin 2012, A5) According to the 2011 Harris/Decima poll, 57\% of respondents said that they were willing to pay more taxes to allow governments to spend on post-secondary education while $33 \%$ disagree. In the same survey, $54 \%$ said government should make lowering fees a top priority in postsecondary education.

The cost of undergraduate tuition has grown dramatically over the past twenty years from an average of \$1,706 in 1990-1991to \$5,138 in 2010-2011 an increase of over $200 \%$. Tuition grew the fastest in Ontario with an increase of $247 \%$ and the slowest at Memorial University in Newfoundland at $70 \%$. In Quebec tuition increased at a rate of 84\% from 1991-1992 to 2010-2011. Ontario students have the highest average tuition at \$6,307 and in Quebec "the average tuition $(\$ 2,415$ in $2010-2011)$ remains the lowest in the country" (CAUT Almanac 2012, 23).

University revenues in Canada are a combination of provincial funding, tuition fees scholarships, bursaries, loans, endowments and private-sector support. The greatest focus on the costs of education has been the rising tuition as a percentage of university operating revenues. While tuition rates vary from province to province and year over year, it is important to note that the highest percentages of tuition as operating are found in Ontario at $44.5 \%$, Nova Scotia at $41.3 \%$, British Columbia at $40.3 \%$ and the lowest are found in Newfoundland Labrador at $15.9 \%$ and in Quebec at $21.1 \%$.

Porter identified income and wealth as a major barrier to education. However Porter did not anticipated the escalating costs of education or the intensity of the debate over tuition fees. The cost of post-secondary education will undoubtedly continue to be the focus of debates and possible student demonstrations and protests. Without a national educational funding policy costs will continue to be a barrier to post-secondary education in Canada. Since education is a provincial matter a national funding policy will be difficult if not impossible. 


\section{Changes in Education and Gender}

A barrier to post-secondary education that Porter did not identify was gender. According to the CAUT Almanac 2011-2012, the gender balance in Canadian universities has changed. Women now represent the majority of university and college students. At the Bachelor level and other undergraduate degrees $58 \%$ of the enrollment are women, $56 \%$ at the Master's level, $54 \%$ at the community college level and $47 \%$ at the $\mathrm{PhD}$ level. Increasingly researchers are asking, what is happening to the boys? What do academic indicators such as test score drop-out rates, decreasing enrollment, and male negative attitude to education mean? Do these indicators illustrate a climate of neglect and as Nikkah observed "the idea that boys somehow need less attention has back fired, and parents and educators are now beginning to understand the adverse effect of not paying attention to boys" (Nikkah 2000, Xiii) Academic testing, high school dropout rates and university and college enrollments suggest that boys are falling behind in post-modern society. Educators, parents, and researchers are asking are boys in academic trouble? Has the classroom and teachers become anti-male? Do boys think their ideas and comments are valued? What do we observe if we examine this academic data in terms of Nikkah's ideas of neglect?

\section{Gender and Education: What about Boys?}

According to Kimmel, at first glance the academic statistics suggest that boys are in trouble. "Boys drop out of school, are diagnosed as emotionally disturbed, and commit suicide four times more often than girls...boys are six times more likely to be diagnosed with Attention Deficit Disorder" (Kimmel 2006, 361) However, Kimmel argues that critics are creating a debate focused on "these three themes-numbers, grades, and behavior" (Kimmel 2006, 362). What is missing, according to Kimmel, is an understanding of the nature of masculinity appropriate for boys and men to succeed. Males may be "hardwired" towards competition and aggression but men are also hardwired towards compassion, nurturing and love." (Kimmel 2006, 372). For boys to succeed in a post-modern society and to excel in education, Kimmel argues that boys must focus less on aggression and more on empathy and compassion.

Ringrose examines the debate on gender and education in Canada and the United Kingdom. She draws attention to the press coverage of the politics of the 'failing boys' debate. Ringrose writes that the "claims about boys underperformance and girls over-performance is exaggerated and played upon by the UK press" (Ringrose 2009, 215. Her research suggests that the academic achievement and superiority of boys in the past has been largely a myth. Introducing the research of Cohen, Ringrose writes that it is "historically inaccurate to suggest that underachievement among boys is something new" (Ringrose 2009:217). What is missing in this whole debate of 'failing boys/successful girls' discourse is that "middle-class white boys continue to 
succeed at school alongside their female counterparts while many workingclass and black boys continue to experience difficulty with educational performance" (Ringrose 2009:221). Ringrose notes that what is missing is why the whole question of under achievement in the schools of Canada and the UK has never been seriously addressed. Nevertheless political leaders, policy makers, educators, and parents groups are concerned about the performance and participation of boys in post-modern society. What do the statistics reveal about the performance of boys and young men in Canadian education?

\section{Education and Government Responsibility}

With so much public and private money allocated to education governments, school boards, policy makers and parents want to ensure that revenue is well spent. Academic testing and analysis are used increasingly to make certain that academic standards are being met. Statistics Canada and provincial ministries of education examine the impact of income, class, education, occupation, race, and gender on academic performance. What does this data reveal about the relationship of gender and academic achievement? What attitudes do boys have toward school?

\section{Statistical Profile and Gender}

The Ontario Ministry of Education has the broad general goal of ensuring the educational attainment of all students in the province. The Ministry's others stated goals are for higher levels of student achievement, reduced gaps in student achievement, and increased pupil confidence in publicly funded education (Ontario Ministry of Education 2011, 5). To ensure that these goals are met, the Ministry administers province wide achievement tests through the Education Quality and Accountability Office (EQAO). This Office evaluates how many grades 3 and grade 6 students meet the provincial scores of 125 out of 200 in the reading and 100 out of 180 in the writing.

According to the 2007/2008 EQAO assessment, in grade 3 reading, 55\% of boys and $68 \%$ of girls met the provincial standards, a difference of $13 \%$. On grade 3 writing assessment, $59 \%$ of boys and $74 \%$ of girl met provincial standards, a difference of 15\%. Similar differences are observed in the grade 6 assessment results; in reading $60 \%$ of boys and $73 \%$ of girls met provincial standards, a difference of $13 \%$. In writing $58 \%$ of boys and $76 \%$ of girls met provincial standards, a difference of $18 \%$ (Ontario Ministry of Educations 2011:5). These results are not that surprising when you examine the attitude of boys and girls to reading and writing. A sample of students from the 2007/2008 testing program for grades 3 and 6 were asked whether they liked reading and writing. The EQAO report reveals that in grade 3, 51\% of boys and $68 \%$ of girls reported that the liked to read and $43 \%$ of boys and $61 \%$ of girls said they 
liked to write. Similar gender differences are found in the grade 6 results, $40 \%$ of boys and $61 \%$ of girls, a difference of $21 \%$, said that they liked to read and $32 \%$ of boys and $51 \%$ of girls, a difference of $19 \%$, reported that they liked to write.

These results clearly indicate that in Ontario, boys do not enjoy school work as much as girls and boys are consistently under performing on reading and writing tests in grade 3 and grade 6. To summarize, in 2007-2008, 13\% fewer boys meet the provincial standard in reading and $15 \%$ fewer boys meet the writing score in grade 3 and in grade $6,13 \%$ fewer boys in reading and $18 \%$ fewer boys in writing meet provincial standards. What are we observing when we examine these academic scores? Are these gender differences found solely in elementary school boys? Will these academic differences be reduced or disappear at the secondary level?

In Ontario, academic testing takes place at the secondary school level in grade 10. The Ontario Secondary School Literacy Test (OSSLT) results indicate that gender differences still exists. The results of the 2007-2008 grade10 testing show that $80 \%$ of boys and $88 \%$ of girls were successful. Similarly, in Canada, at the national level Chart 1 illustrates gender differences in the academic achievement of boys and girls age 15 years old.

Chart 1. Distribution of Average Overall Marks, 15years by Gender

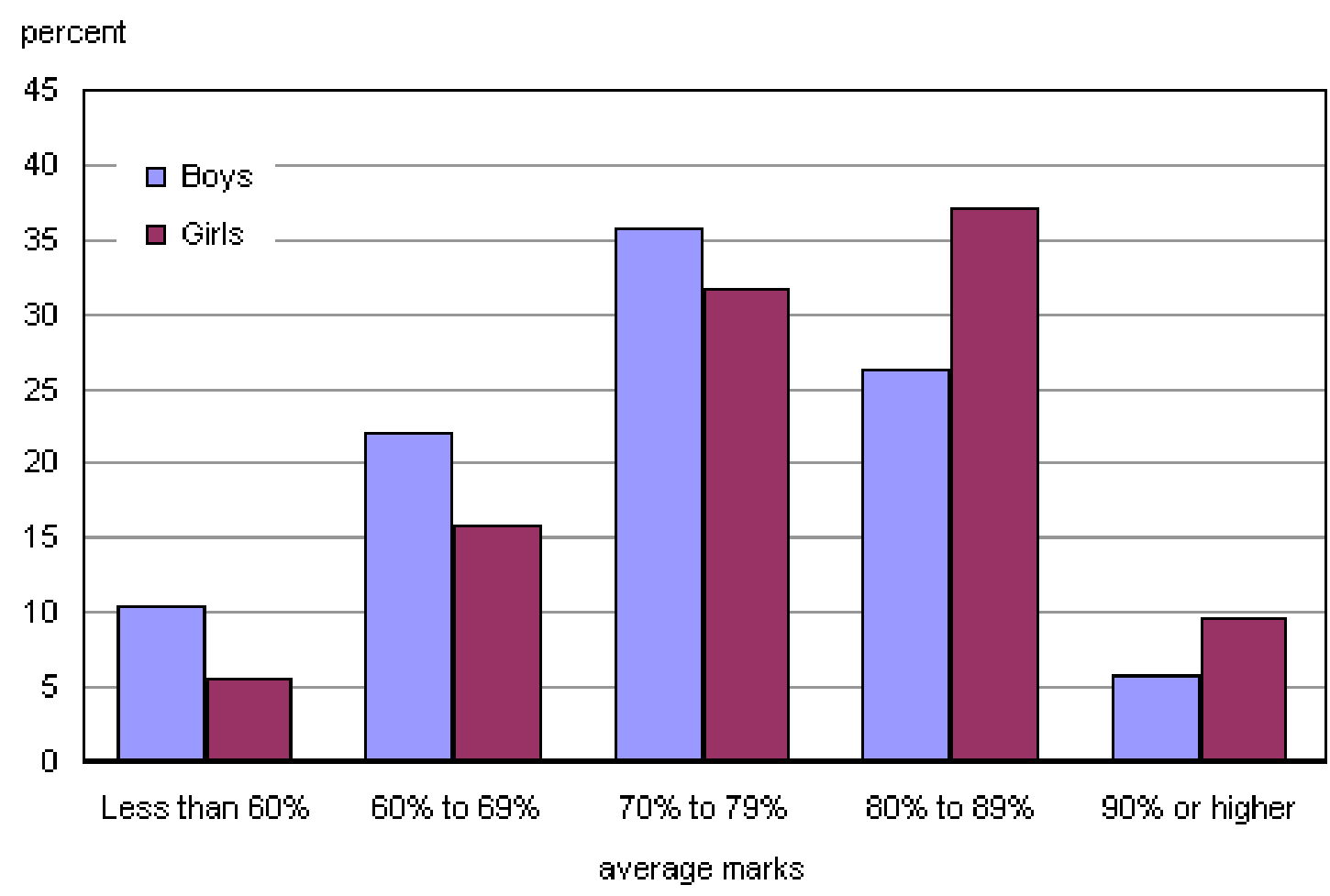

Source: "Youth in Transition Survey" Statistics Canada (2007) p.2

First, it is apparent from Chart 1 that the academic performance of boys significantly differs from that of girls. For example, in the marks category of 
"less than $60 \%$ ", you find $10 \%$ of boys and only $5 \%$ of girls. By contrast at the upper range of " $90 \%$ or higher" marks there are slightly over $5 \%$ of boys and just under $10 \%$ of girls. The academic performance of boys versus girls begins to change at the marks category of $70 \%$ to $79 \%$. The academic performance of girls is also dramatically greater than boys at the " $80 \%$ to $89 \%$ " level.

In Ontario the dropout rate from secondary school has declined for both boys and girls from 1990-1991 to 2004-2005. In 1990-1991 the drop out rate was $19.2 \%$ for boys compared to $14.0 \%$ for girls and in 2004-2005 the drop out rate was $12.2 \%$ for boys and $7.2 \%$ for girls. Boys are $5 \%$ higher than girls in each time period. In 2004-2005, 135,300 boys and 77,200 girls dropped out of school.

Table 1. High School Engagement Indicators (Percent)

\begin{tabular}{|c|c|c|c|c|c|c|}
\hline & \multicolumn{3}{|c|}{ Graduates } & \multicolumn{3}{|c|}{ Dropouts } \\
\hline & Total & Men & Women & Total & Men & Women \\
\hline \multicolumn{7}{|l|}{ \% Most or All of the Time: } \\
\hline I got along well with teachers. & 88.6 & 85.0 & 91.8 & 60.1 & 53.4 & 71.2 \\
\hline $\begin{array}{l}\text { I did as little work as possible; I } \\
\text { just wanted to get by. }\end{array}$ & 14.9 & 20.8 & 9.4 & 34.5 & 39.6 & 26.0 \\
\hline I paid attention to the teacher. & 82.1 & 76.8 & 87.0 & 60.1 & 54.8 & 68.6 \\
\hline $\begin{array}{l}\text { I was interested in what I was } \\
\text { learning in class. }\end{array}$ & 60.4 & 54.8 & 65.7 & 43.6 & 38.3 & 52.2 \\
\hline $\begin{array}{l}\text { I felt like an outsider or like I was } \\
\text { left out of things at school. }\end{array}$ & 3.5 & 3.7 & 3.3 & 14.2 & 13.5 & 15.1 \\
\hline I completed my homework on time. & 80.4 & 74.0 & 86.3 & 48.1 & 39.7 & 61.5 \\
\hline \multicolumn{7}{|l|}{ \% Agree or Strongly Agree: } \\
\hline $\begin{array}{c}\text { I thought that many of the things } \\
\text { we were learning in class were } \\
\text { useless. }\end{array}$ & 38.7 & 40.4 & 37.3 & 55.4 & 59.1 & 49.5 \\
\hline $\begin{array}{l}\text { I was treated with as much respect } \\
\text { as other students in my class. }\end{array}$ & 91.7 & 91.5 & 92.0 & 74.4 & 76.5 & 71.0 \\
\hline $\begin{array}{l}\text { I had friends at school whom I } \\
\text { could talk to about personal things. }\end{array}$ & 94.5 & 93.4 & 95.5 & 84.0 & 83.9 & 84.3 \\
\hline $\begin{array}{l}\text { I liked to participate in many school } \\
\text { activities, for example clubs, sports, } \\
\text { drama. }\end{array}$ & 62.1 & 61.8 & 62.5 & 37.8 & 41.4 & 32.0 \\
\hline School was often a waste of time. & 13.2 & 16.6 & 10.0 & 36.3 & 39.8 & 30.4 \\
\hline $\begin{array}{l}\text { People at school were interested in } \\
\text { what I had to say. }\end{array}$ & 90.5 & 89.9 & 91.0 & 78.8 & 80.3 & 76.4 \\
\hline
\end{tabular}

Source: "At a Crossroads: First Results for the 18-20 Year-old Cohort the Youth Transition Survey" Statistics Canada (1999) p.2

Table 1 provides a picture of what men and women, graduates or dropouts, 
think of the culture of public education. For example, $91.8 \%$ of women and $85.0 \%$ of men graduates, compared to $71.2 \%$ of women and $53.4 \%$ of men dropouts reported "getting along well with teachers". Statistically $6.8 \%$ more women graduate and $17.8 \%$ more women who are dropouts reported getting along with teachers than men who graduate or drop-out. Men did not get along as well with teachers as did their women counterparts. As well as attitudes to teachers, reaction to the content of the curriculum is an important indicator of academic success. In Table 1, 65.7\% of women and $54.8 \%$ of men graduates compared to $52.2 \%$ of women and $43.6 \%$ of men dropouts reported that they were "interested in what I was learning in class". Statistically, $10.9 \%$ more women who are graduates and $8.6 \%$ more women who are dropouts were interested in their curriculum than men.

Table 1 provides an understanding of the dimensions of gender and education. For example, $91.5 \%$ of men who graduated compared to $76.5 \%$ who drop out, a $15 \%$ difference reported that they were "treated with as much respect as other students". As well $89.9 \%$ of men that graduated report that they considered their views were of "interest to others" while $80.3 \%$ of the men who dropout considered their views were of "interest to others". To participate in a social institution you must assume you are respected by others and their ideas are of interest. This acceptance is especially important to young people 15 to 20 years old. For school and education to be a life-long process there needs to a cultural change so that boys and young men increasingly self-define themselves as valued and respected. We are observing what Porter calls a psychological barrier to education. Boys have a negative attitude and value towards education and are not the motivated to participate. If boys do not get along with teachers and their views are not of interest to others, school and/or education is surely not the place to be.

\section{Current Data and Possible Solutions?}

According to some researchers boys are doing as well as ever in school and the current debate on gender is only the result of girls performing better than ever. Statistics indicates that girls are increasingly graduating from secondary school, entering colleges and university and enrolling in nontraditional fields of study. These trends are changing the profile of Canadian education. Does this data suggest that the gender debate has less to do with failing boys and more to do with over-achieving girls?

For Kimmel and Ringrose this debate is not about feminism and the feminist movement but more about the media's attention to gender and education. However, how do we deal with the statistic that 135,300 men compared to 77,100 women dropped out of school in Canada in 2004-2005? Is it not disingenuous to suggest that the dropout rates, the underachievement and the academic performances of boys do not identify a serious issue? How do we address the premise that boys are in trouble? What changes can teachers and parents make to the context and content of education for boys? 
After the publication of Why Gender Matters in 2005, Sax has heard numerous explanations "for why so many boys are having trouble connecting with school." (Sax 2007, 4). Parents complain that their sons, though very bright, will not do homework or engage in school! Sax writes that some parents blame the school, the lack of male role models, video games, Hollywood, society, or the lack of funding for education. As a family physician with a $\mathrm{PhD}$ in psychology, Sax has seen thousands of patients and "hundreds of families where the girls are the smart, driven ones, while their brothers are laid back and unmotivated. The opposite pattern - with the boys being the intense, successful child while his sister is relaxed and unconcerned about her future - is rare." (Sax 2007, 4). In his latest book Boys Adrift, Sax examines various factors from changes in schools, to medication for ADHD that may account for the lack of interest in school and academic achievement by boys. While his findings are informative, I believe it is his discussion on core values that provides insight into the academic achievement and the dropout rate of boys.

After giving the commencement address at Avon Old Farm, a private school for boys, Sax observed there were many girls visiting from a local co-ed school. One girl said they came frequently to Avon Old Farm because the boys are gentlemen. Another girl stated that "the boys at our school are all total losers. .... They are loud, and obnoxious and annoying....It's totally nauseating" (Sax 2007, 164). Sax does not suggest that all boys' schools are great or that all boys in co-ed schools are social failures but Avon Old Farm has an excellent reputation with its peers on the quality and character of the boys. Sax notes that this reputation seemed to be centered on the eight core values of the school. At the top of the list is scholarship followed by integrity, civility, tolerance, altruism, sportsmanship, responsibility and self-discipline. Sax argues that the comments that the students of Avon Old Farm are gentlemen was learned behavior "a boy does not naturally become a gentleman....That behavior is not hardwired. It has to be taught."(Sax 2007, 163) By consciously encouraging these core values at Avon Old Farm, there is a dramatic difference in social and academic behavior of its male students. According to Nikkak's "the idea that boys somehow need less attention has backfired, and parents and educators are now beginning to understand the adverse effects of not paying attention to our boys" (Nikkak 2000, xiii).

The private, same gendered schools system in Canada promotes their commitment to academic achievement, broader academic opportunities and the quality of the academic environment. While not every boy would do well in such an educational system, the 2009/2010 Canada's Private School Guide, promotes the private schools' commitment to academic success and an educational environment that helps boys grow and mature. Students and educators argue that the private school system has the right academic structure and value system for boys. A graduate of the all boys Royal St. George College in Toronto noted that his private school experience gave him the opportunity to separate his school life from his social life. After years at co-ed school he enrolled in a private boys school and stated that "I took some intensive 
advanced courses and I took on leadership positions within the school - both of which I might not have done in a coed environment". (Elsen 2010, 32). While educators in private schools have an obvious vested interest, their positive comments parallel those of students. Brad Adams, Executive Director of the International Boys' School Coalition, states that "single gender schools also offer a safe place for boys to take risks, express their emotions and explore subjects such as the arts and literature." (Elsen 2010, 32) The private school system seems prepared to give boys freedom and to recognize that academic development differs with gender and age. Kathryn Kirkland, head of the Junior School at Royal St. George College states that "boys in the primary years often lag 18 months cognitively behind girls "if you're constantly being told to sit down and be quiet, then it starts to affect your happiness and self-perception as a student and a learner" (Elsen 2010,33)

\section{Conclusion}

In a credentialed society such as Canada university degrees, college diplomas, and trade school certificates are essential for social and economic success. Nearly $80 \%$ of Canadian considers getting a university or college education more important than ever. However there are cultural and social barriers to post-secondary education. For Porter these barriers are both psychological and social. As more students graduate with increased debts, governments, students and families question whether students can afford a university or college education. As important as education is to the general population the lack of income and wealth continues as a social barrier to postsecondary education. Will the questions of financing higher education take the form of the student protests as in Quebec or as political debates on educational policy?

As the need for an educated population continues no barrier to education can be ignored. Porter did not anticipate gender to be a social barrier. There is no doubt that for many, gender has increasingly acted as a social barrier to education. In the 1960's as my Father and I drove from the rural bank in Ontario we were obviously addressing the financial barrier. However my Father's willingness to borrowed money to finance my first year at university also affirmed the values of a young man for a post-secondary education.

It seems to me that the future success of boys, in public or private schools, is found in the values and actions of the past. Parents need to encourage and support the dreams of their children for post-secondary education with financial and moral support. Educators today also need to affirm their commitment to solid teacher/student relations, to emphasize their respect for students' interests and ideas, and to exercise greater flexibility in gender differences.

I am not sure that on that September day my Father and I fully understood what his bank loan meant. He not only financed my first year at university but also affirmed his commitment to a young man's dream of a post-secondary 
education.

\section{Bibliography}

"At a Crossroads: First Results for the 18-20 Year-old Cohort of the Youth in Transition Survey" Statistics Canada (1999)

CAUT Almanac of Post-secondary Education in Canada 2011-2012 (2012) Canadian Association of University Teachers

CAUT Bulletin (2011) Canadian Association of University Teachers Vol. 58 No. 4.

CAUT Bulletin (2012) Canadian Association of University Teachers V01 59 N0.3

Corbett, M. (2009) 'The Road to School Leads Out of Town: Rurality and Schooling in Atlantic Canada' In Canadian Perspectives on the Sociology of Education C. Levine-Rasky (ed.) Don Mills, Ontario: Oxford University Press. 233-251

Elsen, Hailey (2010) “Boys' School” Our Kids Go to School 2009/2010 Directory The Globe and Mail 32-34.

"EQAO School and School Board Reports" Ontario Ministry of Education (Toronto, Ontario: Queens Printer, 2011)

Kimmel, M. (2006) "What About the Boys?" What the Current Debate Tell Us -and Don't Tell Us-About Boys in School In Reconstructing Gender E. Disch New York: McGraw-Hill. 361-375

Nikkah, John. (2000) Our Boys Speak: Adolescent Boys Write about Their Inner Lives New York: St Martin's Griffin.

Porter, John. (1965) The Vertical Mosaic: An Analysis of Social Class and Power in Canada Toronto: University of Toronto Press.

Ringrose, J. (2009) 'The Future Is Female': The Post-feminist Panic over Failing Boys" In Canadian Perspectives on the Sociology of Education C. Levine-Rasky (ed.) Don Mills, Ontario: Oxford University Press. 213-226

Sax, Leonard (2007) Boys Adrift: Five Factors Driving the Growing Epidemic of Unmotivated Boys and Underachieving Young Men. New York: Basic Books.

"Youth in Transition Survey" (2003) Statistics Canada p.1-3 
